\title{
Distal Tibial Fractures Managed by Minimally Invasive Plating Osteosynthesis: A Prospective Study
}

\author{
Amit Kumar $^{1}$, Sanjeev Gupta ${ }^{2}$, Vinay Badyal ${ }^{3}$ \\ ${ }^{1}$ PG 3rd Year, Department of Orthopaedics, GMCH Jammu, J\&K \\ ${ }^{2}$ Professor and Head of Department, Department of Orthopaedics, GMCH Jammu, J\&K \\ ${ }^{3}$ Department of Oral Medicine and Radiology, Consultant at Oracare Clinic, J\&K \\ Corresponding Author: Sanjeev Gupta
}

\begin{abstract}
Background: Distal tibial fracture is a common results of road traffic accidents and fall injuries. The treatment of tibial fractures is very important and this bone is very subcutaneous associated with soft tissue injury and precarious blood supply. Distal tibial fractures require accurate reduction, followed by perfect articular reduction then stable fixation with minimally stripping of soft tissues.
\end{abstract}

Aim: Distal tibial fractures managed by minimally invasive plating osteosynthesis: a prospective study.

Methodology: The prospective study was taken in GMC Jammu from 2019 -2020 in Department of Orthopaedics. All patients are approved by the ethical clearance of the same hospital from 2019-2020. 32 cases of the distal tibial fracture is were admitted according to which twenty two male and ten females. All the necessary data collected and reported to separate sheets.

Results: In our study two age group were taken 19-40 and 41-60. About 19-40 group was majority in fractures distal tibia. In our observation around 22 males and around 10 females were noted. Around $68.7 \%$ were males and around $31.2 \%$ were females they were affected. In our observation closed or open fractures is noted and around 75\% (24) patients are closed and 25\% (8) patients were open. In our observation AO/OTA classification 43-A1 is the most common classification which was around $65.6 \%$ (21) patients then $43-\mathrm{A} 2$ is the $15.6 \%, 43-\mathrm{A} 3$ is about $12.5 \%$ and $43-\mathrm{B} 1$ is around $6.2 \%$.
Conclusion: In our study it is concluded that all the fracture are due to road traffic accidents and fall from height. In our patients around superficial infection, varus angulation and implant failures are very less and similar to other studies done by other authors. Soft tissues handling and the minimally invasive plating osteosynthesis (MIPPO) allows early rehabilitation and excellent functional outcome.

Key Words: distal tibia, MIPPO, closed fractures

\section{INTRODUCTION}

Distal tibia fractures are a common result of road traffic accidents and fall injuries.[1] The treatment of distal tibial fractures is very important and challenging due to the limited subcutaneous, soft tissue injury and poor vascularity.[2,3] Fracture pattern (proximity of the fracture to the plafond, comminution), soft tissue injury, and bone quality critically influence the selection of the fixation technique.[4] A variety of treatments may be used, intramedullary nailing, including external fixation, and plate fixation.[1,5] Traditional open reduction and intra-operative plate fixation is very impressive but complication rate is very high requires extensive soft tissue dissection and periosteal stripping, and these factors increase the rates of complications, including infection, delayed union and non-unions.[6,7] Minimally invasive plate osteo-synthesis techniques 
Amit Kumar et.al. Distal tibial fractures managed by minimally invasive plating osteosynthesis: a prospective study.

has been developed in recent years,[1] with high union rates.[8] This technique aims to reduce surgical trauma and maintain a more biologically favorable environment for fracture healing. However, complications, such as angular deformities, hardware failure, and non-unions have been reported. [9-11]

\section{METHODS}

The prospective study was taken in GMC Jammu from $2019-2020$ in Department of Orthopaedics. All patients is approved by the ethical clearance of the same hospital from 2019-2020.

32 cases of the distal tibial fracture is were admitted according to which twenty two male and ten females. All the necessary data collected and reported to separate sheets.

\section{Inclusion criteria}

1. Skeletally mature person.

2. Gustilo-Anderson closed/ grade 1 open fracture.

3. Distal tibial metadiaphyseal fracture.

\section{Exclusion criteria}

1. Pathological fracture.

2. Lack of fallow -up.

3. displaced intra-articular fracture.

Complications were noted like nonunion, callus formation, late healing, malunion, and infection.

\section{RESULTS}

\section{Age of patients.}

\begin{tabular}{|l|l|l|l|}
\hline s. no & Age in years & No of patients & Percentage \\
\hline 1 & $19-40$ & 20 & $62.5 \%$ \\
\hline 2 & $41-60$ & 12 & $37.5 \%$ \\
\hline
\end{tabular}

In our study two age group were taken 19-40 and 41-60. About 19-40 group was majority in fractures distal tibia.

\section{Sex incidence.}

\begin{tabular}{|l|l|l|l|}
\hline S.no & Sex & No of patients & Percentage \\
\hline 1 & Male & 22 & $68.75 \%$ \\
\hline 2 & Female & 10 & $31.25 \%$ \\
\hline
\end{tabular}

In our observation around 22 males and around 10 females were noted. Around $68.7 \%$ were males and around $31.2 \%$ were females they were affected.

\section{Mode of injury.}

\begin{tabular}{|l|l|l|l|}
\hline s.no & Mode of injury & No of patients & Percentage \\
\hline 1 & RTA & 25 & $78.12 \%$ \\
\hline 2 & Fall & 7 & $21.8 \%$ \\
\hline Total & & 32 & $100 \%$ \\
\hline
\end{tabular}

In our observation around 25 patients is RTA and 7 were fall from height.

4. Type of fractures.

\begin{tabular}{|l|l|l|l|}
\hline s.no & Type of fractures & No of patients & Percentage \\
\hline 1 & Closed & 24 & $75 \%$ \\
\hline 2 & Open & 8 & $25 \%$ \\
\hline Total & & 32 & $100 \%$ \\
\hline
\end{tabular}

In our observation closed or open fractures is noted and around 75\% (24) patients are closed and 25\% (8) patients were open.

\section{5. type of fracture according to AO/OTA classification}

\begin{tabular}{|c|c|c|c|}
\hline S.NO & $\begin{array}{l}\text { OTA } \\
\text { TYPE }\end{array}$ & $\begin{array}{ll}\text { NO. } & \text { OF } \\
\text { PATIENTS } & \end{array}$ & $\begin{array}{l}\text { PERCENTAGE } \\
\%\end{array}$ \\
\hline 1 & 43-A1 & 21 & $65.62 \%$ \\
\hline 2 & 43-A2 & 05 & $15.62 \%$ \\
\hline 3 & 43-A3 & 04 & $12.5 \%$ \\
\hline 4 & 43-B1 & 02 & $6.25 \%$ \\
\hline TOTAL & & 32 & $100 \%$ \\
\hline
\end{tabular}

In our observation AO/OTA classification 43-A1 is the most common classification which was around 65.6 (21) patients then $43-\mathrm{A} 2$ is the $15.6 \%, 43-\mathrm{A} 3$ is about $12.5 \%$ and $43-\mathrm{B} 1$ is around $6.2 \%$.

\section{Time to full weight bearing.}

\begin{tabular}{|l|l|l|l|}
\hline s.no & $\begin{array}{l}\text { Time of full weight } \\
\text { bearing(weeks) }\end{array}$ & $\begin{array}{l}\text { No of } \\
\text { patients }\end{array}$ & Percentage\% \\
\hline 1 & $12-16$ & 27 & $84.3 \%$ \\
\hline 2 & $>16$ & 05 & $15.62 \%$ \\
\hline TOTAL & & 32 & $100 \%$ \\
\hline
\end{tabular}

In our observation full weight bearing within the 12-16 weeks is about 84.3\% (27) patients and then around 15.6\% (05) patients have union rate is around $>16$ weeks. 

study.

\section{Showing complications}

\begin{tabular}{|l|l|l|l|}
\hline S.no & Complication & $\begin{array}{l}\text { No of } \\
\text { patients }\end{array}$ & $\begin{array}{l}\text { Percentage } \\
\text { \% }\end{array}$ \\
\hline 1 & $\begin{array}{l}\text { Superficial skin } \\
\text { infection }\end{array}$ & 3 & $9.3 \%$ \\
\hline 2 & Deep infections & 0 & \\
\hline 3 & Skin necrosis & 0 & \\
\hline 4 & Non-union & 0 & $9.3 \%$ \\
\hline 5 & $\begin{array}{l}\text { Varus angulation 5-7 } \\
\text { deg. }\end{array}$ & 3 & $3.1 \%$ \\
\hline 6 & Implant failure & 1 & $100 \%$ \\
\hline Total & & & \\
\hline
\end{tabular}

In our study complication like superficial infection 9.3\%, varus angulation 9.3\% and then implant failure around 3.1\% is noticed.

\section{AOFAS score.}

\begin{tabular}{|l|l|l|l|}
\hline s.no & AOFAS score & No of patients & Percentage \% \\
\hline 1 & Excellent & 27 & $84.3 \%$ \\
\hline 2 & Good & 05 & $15.7 \%$ \\
\hline 3 & Fair & 00 & 00 \\
\hline
\end{tabular}

In our study AOFAS score are $84.7 \%$ in excellent form and around $15.7 \%$ is in good results.

\section{DISCUSSIONS}

Distal tibial fracture is very common and difficult to treat the fracture because of different in blood supply and location of the affected part. Various modalities for the fixation of these fractures are available like internal fixation, external fixation in nailing.

In our study, it was found that distal tibial fractures were common in 19-40 year age group and males were predominately as compared to females. In our study males were $68.7 \%$ and females were $32.3 \%$ were affected. The similar results were reported by Hazarika et al, Leung et al, Mushtaq et al.

In our observation mode of injury was the RTA and fall in $78.12 \%$ and $21.87 \%$ patients and this is again proven in our study ${ }^{17-19}$. in contrast Maruthi et al. 20 reported fall as the main cause of fracture, which was the second most common cause in our study.

in our study closed injury was the most common around $75 \%$ and $25 \%$ are open injury. the observation made by our study is comparable to those previously reports in our study we used AO/OTA classification to classified the injury pattern in our patients. The most common was 43A1 which was about $65.6 \%$ and then $43-\mathrm{A} 2$ which was about $15.6 \%$ after which $43-\mathrm{A} 3$ and $43-\mathrm{B} 1$ which was around $12.5 \%$ and $6.25 \%$. similar result is found in the studies of Leung et al, Ronga et al, Faschingbauer et al.

in our observation time to bony union is about $84.3 \%$ around $14-18$ weeks and around $15.6 \%$ around $18-21$ weeks. our observation is very similar to Mustaq et al, Ronga et al, Bahari et al, Zha et al and Collinge et al, had almost similar results in their studies.

In our study the complication rate is about $6.25 \%$ having the superficial infection $3.1 \%$ having the deep infections and 9.4\% patients have the varus angulation and 1 have implant failure. Our observation is very similar to studies conducted by Portzman et al.

In our study AOFAS ankle and hind foot score was applied and analyses the outcome of the patients. Final outcome of the AOFAS score is $84.3 \%$ in excellent form and then $15.7 \%$ is in good form.

\section{CONCLUSION}

In our study it is concluded that all the fracture are due to road traffic accidents and fall from height. In our patients around superficial infection, varus angulation and implant failures are very less and similar to other studies done by other authors. Soft tissues handling and the minimally invasive plating osteosynthesis (MIPPO) allows early rehabilitation and excellent functional outcome.

Acknowledgement: None

Conflict of Interest: none declared

Source of Funding: None

Ethical Approval: Approved 


\section{REFERENCES}

1. Russell TA. Fractures of the tibia and fibula. In Rockwood CA, Green DP, Buckolz RW, Heckman JD, editors. Fractures in adults. 4th ed. Philadelphia: Lippincott, 1996: 2139-2157.

2. Kneifel T, Buckley R. A comparison of one versus two distal locking screws in tibial fractures treated with undreamed tibial nails: a prospective randomized clinical trial. Injury. 1996;27: 271-3.

3. Trafton PG. Tibial Shaft fractures. In: Browner DB, Jupiter JB, Levine AN, Trafton PG, Krettek C (eds). Skeletal trauma. 4th ed. Philadelphia: Saunders Elsevier.; 2009: 2319-2452.

4. Mosheiff R, Safran O, Segal D, Liebergall $M$. The unreamed tibial nail in the treatment of distal metaphyseal fractures. Injury. 1999;30:83-90.

5. Ruedi TP. Murphy WM. AO principles of fracture management. New York: Thieme Medical Publishers: 2001: 253-255.

6. Fisher WD, Hambledon DL. Problems and pitfalls of compression fixation of long bone fractures: a review of results and complications. Injury. 1978;10:99107.

7. McFerran MA, Smith SW, Boulas HJ, Shwartz HS. Complications encountered in treatment of pilon fractures. J Orthop Trauma. 1992;6:273-85.

8. Olerud S, Karlstrom G. Tibial fractures treated by AO Compression osteosynthesis. Acta Orthop. Scand Suppl. 1972;1:1-104.

9. Ruedi T, Allgower M. Fractures of lower end of tibia into the ankle joint. Injury. 1969;1:92.

10. Ruedi T, Allgower M. The operative treatment of intra-articular fractures of lower end of tibia. Clin Orthop. 1979;138:105-10.

11. Tornetta $\mathrm{P}$, Weiner L, Bergman $\mathrm{M}$, Watnik N, Steuer J, Kelley M, et al. Pilon fractures: treatment with combied internal and external fixation. J Orthop Trauma. 1993;7:489-96.

12. Hazarika S, Chakravarthy J, Cooper J. Minimally Invasive locking plate osteosynthesis for fractures of distal tibia.
Results in 20 patients. Injury. 2006; 37(9):877-87.

13. Leung FK, Law TW. Application of minimally invasive locking compression plate in treatment of distal tibial fractures. Zhongguo Xiu Fu Chong Jian Wai Ke Za Zhi. 2009;23:1323-5.

14. Mushtaq A, Shahid R, Asif M. Distal tibia fractures fixation with locking compression plate using MIPPO technique. Eur J Trauma Emerg Surg. 2009;35:159-64.

15. Lee YS, Huang CC, Chen CN, Lin CC. Operative treatment of displaced lateral malleolar fractures: the Knowles pin technique. J Orthop Trauma 2005;19(3): 192-7.

16. Motwani GN, Shah HD, Chavli VH, Daveshwar RN, Parmar H, Suthar PP. Results of open reduction and internal fixation in closed bimalleolar Pott's fracture of ankle in adults. Int J Med Sci Public Health 2015;4(7):893-900.

17. Kulloli SS, Magdum PB, Naik NP. Evaluation of management of malleolar fractures of ankle joint. IOSR J Dent Med Sci 2012;3:27-31.

18. Maruthi CV, Venugopal N, Nanjundappa HC, Siddalingaswamy MK. Bimalleolar fracture of ankle joint managed by tension band wiring technique: A prospective study. Sch J Appl Med Sci 2014; 2(1D):428-32.

19. Faschingbauer M, Kienast B, Schulz AP. Treatment of distal lower leg fractures: Results with fixed angle plate osteosynthesis. Eur J Trauma Rmerg Surg. 2009;35:513-9.

20. Ronga M, Longo UG, Maffulli N. Minimally invasive locked plating of distal tibial fractures is safe and effective. CORR. 2009;468:110-4.

21. Collinge C, Kuper M, Larson K, Protzman R. Minimally treatment of high energy metaphyseal distal tibial fractures. J Orthop Trauma. 2007;21:355-61.

22. Bahari S, Lenehan B, Khan H, McElwain JP. Minimally Invasive percutaneous plate fixation of distal tibia fractures. Acta Orthop Belg. 2007;73:635-40. 
Amit Kumar et.al. Distal tibial fractures managed by minimally invasive plating osteosynthesis: a prospective study.

23. Jha G, Chen Z, Qi X. Minimally invasive percutaneous locking compression plate internal

24. fixation in the treatment of distal tibial fractures. Zhongguo Xiu Fu Chong Jian Wai Ke Za Zhi. 2008;22:1448-50.

25. Protzman R, Collinge C. Outcomes of minimally invasive plate osteosynthesis for metaphyseal distal tibial fractures. J Orthop Trauma. 2010;24:24-9.

How to cite this article: Kumar A, Gupta S, Badyal V. Distal tibial fractures managed by minimally invasive plating osteosynthesis: a prospective study. International Journal of Research and Review. 2021; 8(11): 370-374. DOI: https://doi.org/10.52403/ijrr.20211146 